\title{
Copper deficiency in tule elk at Point Reyes, California
}

PETER J.P. GOGAN, DAVID A. JESSUP, AND MARK AKESON

\section{Abstract}

Tule elk (Cervus elaphus nannodes) reintroduced to Point Reyes, Calif., in 1978 exhibited gross signs of copper deficiency by June 1979. Copper levels in liver $(\bar{x}=5.9 \mathrm{ppm})$ and serum $(0.42$ ppm) of elk at Point Reyes were below levels in adult tule elk from other locations in California (liver, $\bar{x} \geq 80$ ppm; serum, $\bar{x} \geq 1.4$ ppm). These levels were consistent with documented copper deficiency in wild and domestic ruminants. Copper serum levels increased in response to copper enriched dietary supplements and declined after the elk stopped eating the supplements. Analysis of plant and soil samples showed both are deffelent in copper and normal in molybdenum and sulfur-sulfates. Deficiency in plants and soils at Point Reyes are probably due to low copper levels in the underlying granitic parent material.

Key Words: Cervus elaphus nannodes, copper, molybdenum and sulfur levels in elk, vegetation and soils

Tule elk (Cervus elaphus nannodes) were reintroduced to the Point Reyes Peninsula in March, 1978, after having been extirpated approximately 100 years earlier (McCullough 1969, Mason 1970). During the first 6 months, the 2 adult male and 8 adult female elk were acclimated in a 1.2-ha pen where they received dietary supplements of alfalfa hay. The adults and 7 calves were released to a 1,030-ha section of Tomales Point, the northernmost part of the peninsula, stocked with beef cattle at $0.4 /$ ha. The elk flourished while in the holding pen and for the first 3 months while free-ranging (Ray 1981); however, by the spring of 1979, the adults exhibited reduced reproductive success, deformed antlers, light pelage, and general lack of thriftiness. Two adults died in July 1979. Discussions with local ranchers and a local veterinarian revealed that beef cattle on Tomales Point regularly received dietary copper $(\mathrm{Cu})$ supplements to prevent severe reproductive problems associated with $\mathrm{Cu}$ deficiency. A tentative diagnosis of $\mathbf{C u}$ deficiency in elk was made based on clinical signs and local history.

The surviving elk at Point Reyes were provided with pelleted alfalfa feed, fresh alfalfa, and commercial livestock feed supplements containing $\mathrm{Cu}$ as copper oxide $\left(\mathrm{CuO}_{2}\right)$, including $13.6 \mathrm{~kg}$ of 12\% Vonco Dairy Pellets (maximum 2\% minerals including $\mathrm{Cu}$ ) and $2.3 \mathrm{~kg}$ of Comet $20 \%$ Pasture and Roughage balance $10.003 \%$ Cu) (Bar Ale, Petaluma, California 94952, USA) daily between mid-September 1979 and early February 1980 and thereafter on alternate days through April 1980, when they ceased taking it. All livestock were removed from the range in November 1979.

The unanticipated pulse of adult mortality and poor condition of surviving elk prompted us to investigate trace element levels in elk, plants, and soils. We determined serum $\mathrm{Cu}$ levels in tule elk at Point Reyes and 4 other locations, and compared liver $\mathrm{Cu}$ and $\mathrm{Mo}$ levels in elk from Point Reyes and Concord Naval Weapons Sta-

\footnotetext{
Author are research aseociate, Department of Forestry and Resource Management, University of Californis, Berkeley 94720; wildlife pathologist, Wildlife Investigations Laboratory, California Department of Fish and Game, 1701 Nimbus Road Suite D, Rancho Cordova, California 95670; and research assistant, Department of Land, Air and Water Resources, University of California, Davis 95616. Gogan is currently wildlife research biologist, Voyageurs National Park, P.O. Box 50, International Falls, Minnesota 56649.

Research was funded in part by National Park Service Contract CX 800-9-0029, Project 3501-MS of the Calffornis A gricultural Experiment Station, Pittman Robertson Project W-52-R, "A Wildlife Investigations Laboratory," and a Rob and Bessie Welder Wildlife Foundation Fellowship to the senior author. Welder Wildife Foundation Contribution 283.

Manuscript accepted 17 November 1988.
}

tion, Contra Costa County, California. We also investigated $\mathrm{Cu}$, $\mathrm{Mo}$ and S-SO ${ }_{4}$ levels in plants and soils at Point Reyes to determine the source of copper deficiency.

\section{Study Area}

The Point Reyes Peninsula, Marin County, lies along the California coastline $65 \mathrm{~km}$ northwest of San Francisco. Elevations range from sea level to $448 \mathrm{~m}$. The tule elk range extends from the northernmost tip of the peninsula $8 \mathrm{~km}$ south to a $2.5 \mathrm{~m}$ high drift fence and includes about 1,030 ha; this area is referred to as Tomales Point. The fence prevents elk movement south.

The climate is moderated by the Pacific Ocean. Mean daily temperatures average $11.4^{\circ} \mathrm{C}$ annually and vary from $9.8^{\circ} \mathrm{C}$ in January to $12.1^{\circ} \mathrm{C}$ in July (Howell 1970). Most precipitation falls from October through April with a long-term annual mean of 95.2 cm recorded at Inverness (Gogan 1986).

The main core of the Point Reyes Peninsula is an isolated body of cretaceous plutonic rocks (Curtis et al. 1958) separated from the Jurassic Franciscan formation of the mainland (Bailey et al. 1964) by the San Andreas fault. Soils classified as the Kehoe Variant Series comprise approximately $90 \%$ of Tomales Point. This soil is a coarse-loamy, mixed isomesic Pachic Paplustoll derived from granitic rock. The soils are moderately deep, well drained and of medium acidity ( $\mathrm{pH}$ 6.0). Sirdrak soils are the most common of the other soil series on Tomales Point. It is a sandy, mixed, isomestic Ustic Dystropepts derived from wind-deposited beach sand or uplifted beach deposits originating from weathered Franciscan rocks of the adjacent mainland. Soils of the Sirdrak series are deep, somewhat excessively drained and from medium (pH 6.0) to slightly (pH. 6.3) acidic. Saline and fresh water aquepts occupy small portions of Tomales Point.

Pristine vegetation has been classified as a coastal prairie-scrub mosaic (Kuchler 1977). The type occurs in a narrow, discontinuous band along the northern coast of California. Point Reyes is one of the few locations where it overlies granitic bedrock. Grazing by domestic stock since the 1830 s has favored establishment of exotic annual grasses and forbs and limited the distribution of native species (Heady et al. 1977). Historically, this vegetation type supported large numbers of tule elk, at least seasonally (McCullough 1969). Tule elk have been extirpated from this type except for recently reestablished populations as at Point Reyes. Black-tailed deer occur at densities of $0.3 /$ ha (Gogan 1986).

\section{Methods}

\section{Animal Samples}

Four elk that died of natural causes were necropsied in the field, the latter 2 within 24 hours of death. A fifth animal died while under treatment and was transported to the Wildlife Investigations Laboratory, California Department of Fish and Game for necropsy. Samples of liver $(N=3)$ and serum $(N=1)$ were obtained when possible. Similarly, liver $(N=5)$ and serum samples $(N=3)$ were obtained from accidental mortalities at Concord Naval Weapons Station, Contra Costa County. Additional serum samples were obtained from tule elk immobilized in the Owens Valley, Inyo County, and Tule Elk State Reserve, Kern County. Analysis of liver samples is most diagnostic of $\mathrm{Cu}$ deficiency in livestock 
(Hartmans 1973). The average value for any element may be misleading, with 1 or 2 values above or below the mean being more indicative than the mean. The proportion of a population exhibiting symptoms of $\mathrm{Cu}$ deficiency may vary (Thornton et al. 1972a).

Serum samples were obtained from tule elk in the spring of 1978 at the time they were transferred to Point Reyes from San Luis Island, Merced Co., California. Subsequently, serum samples were taken at irregular intervals between August 1979 and April 1981. Sample sizes for tule elk at Point Reyes are relatively small in absolute terms-3 to 6-for any sample period. However, such samples repesent 30 to $35 \%$ of the total population, respectively. Elk at Point Reyes suffered from a concurrent outbreak of paratuberculosis (Jessup et al. 1981). We excluded samples from animals ultimately diagnosed as positive for paratuberculosis. However, the test for paratuberculosis is not definitive (Jessup et al. 1981), and it is possible that some elk testing negative were infected.

An emaciated tule elk male was immobilized at Point Reyes in July 1979, and was transferred to Grizzly Island State Wildlife Area, Solano County. At Grizzly Island, the animal received an injection of $120 \mathrm{mg}$ copper glycinate (Cuprate, Burns Biotec, Oakland, California 94621, USA) and a $\mathrm{Cu} \mathrm{SO} \mathrm{SO}_{4}$-enriched diet of pelleted alfalfa feed and fresh alfalfa. It was subsequently released to free-range in April 1980. This male was again immobilized in May and July 1980 for serum samples.

$\mathrm{Cu}$ levels in liver and serum were determined by atomic absorption spectrometry (Varian 475, Varian Co.). Mo levels were determined at $470 \mathrm{Nm}$ (Spec. 20, BNL Co.). These analyses were conducted by a commercial laboratory (California Analytical Labs, Inc.).

\section{Soil and Plant Samples}

A Universal Transverse Mercator grid of 4-ha cells was applied to a Soil Conservation Service aerial photograph at a scale of 1:7,280. Thirty-six cells representing the major soil series and vegetative communities of Tomales Point were selected at random for intensive sampling and for placement of grazing exclosures constructed in a randomly selected quadrat of each cell. We selected 36 additional cells to ensure that all soil series, slopes, aspects and special range conditions were sampled. Common plant species were sampled at these 36 intensive sampling stations in October 1980 and February 1981. We sampled both soils and vegetation at all sites in May 1981.

We collected soil samples from circular areas with an outer radii of $6 \mathrm{~m}$ and inner radii of $3 \mathrm{~m}$ surrounding each of the 72 quadrat center points. Ten locations were randomly selected within each sampling zone, and soils sampled at $0-15 \mathrm{~cm}, 15-30 \mathrm{~cm}$, and $30-45$ $\mathrm{cm}$ depths. Samples from each of the 3 depths were composited. Soil samples were air-dried, crushed with a mortar and pestle, and sieved through a 20 -mesh screen. We placed approximately $250 \mathrm{mg}$ of the fine ground soil in a teflon bomb and mixed it with $1 \mathrm{ml}$ of Aqua Regia (3 parts of $12 \mathrm{~N} \mathrm{HCl}, 1$ part $15 \mathrm{NHNO}_{3}$ and $3 \mathrm{ml}$ of $\mathrm{HF}$ (48\%). The bomb was then closed and heated at $130^{\circ} \mathrm{C}$ for 1 hour, or in some cases, at $110^{\circ} \mathrm{C}$ for 3 hours. After cooling, we added approximately $218 \mathrm{~g} \mathrm{of} \mathrm{H}_{3} \mathrm{BO}_{3}$ to the contents of the bomb to neutralize the remaining HF. We then transferred the contents to volumetric flasks, diluted to volume with double-distilled water and transferred a suitable aliquot to a porcelain crucible to be evaporated ty dryness at $70^{\circ} \mathrm{C}$. After cooling, $3 \mathrm{ml}$ of $2 \mathrm{~N} \mathrm{HCl}$ were added. After sitting for $\mathbf{2 4}$ hours, the solution was transferred to a volumetric flask, diluted to volume and then filtered. We determined available soil Cu by extraction with a DTPA (diethylenetriaminepentaacetic acid) solution (Brown and DeBoer 1978). Mo in the solution was determined by flameless atomic absorption spectrometry.

We collected 2 to 5 plant species at the 36 intensive sampling stations in October 1980 and Feburary 1981 and at all locales in
May 1981, selecting those species abundant at a given site or known to constitute a large portion of the elk diet (Gogan 1986). Two species abundant on the range, plantain (Plantago lanceolata) and soft chess (Bromus mollis), were sampled wherever possible. Ten to 20 individual plants of each species were collected and composited. The entire above-ground portions of grasses and forbs (but only the terminal $8 \mathrm{~cm}$ of new growth of shrubs) were collected.

Plant samples were oven-dried and ground in a Wiley mill to pass a 20-mesh screen. After thoroughly mixing the ground plant material, we dry-ashed 1-to 2-g samples at $580^{\circ} \mathrm{C}$. The ashed residue was dissolved in $20 \mathrm{ml}$ of $5 \% \mathrm{HCl}$. We determined $\mathrm{Cu}$ and Mo in the digests by flame atomic absorption and graphite furnace atomic absorption, respectively, with a Model 560 Perkin-Elmer spectrophotometer. Plant $\mathrm{S}_{-} \mathrm{SO}_{4}$ levels were measured following the method of Johnson and Nishita (1952).

\section{Results}

\section{Animal Trace Element Levels}

The liver copper content of the 3 tule elk that died at Point Reyes ranged from 1.9 to $10.0 \mathrm{ppm}$ (Table 1). Values for four 6-monthold tule elk calves at Concord exceeded $16 \mathrm{ppm}$, and the level for a

Table 1. Liver Cu and Mo values (ppm) of tule elk from Point Reyes and Concord.

\begin{tabular}{|c|c|c|c|c|c|}
\hline Location & Date & Age/Sex & $\mathrm{Cu}$ & Mo & Comments \\
\hline Reyes & Jul. 79 & $1 \mathrm{yr} /$ female & 4.7 & 5.0 & $\begin{array}{l}\text { Natural death; } \\
\text { cause unknown. }\end{array}$ \\
\hline t. Reyes & Aug. 79 & Adult/female & 3.1 & 5.4 & $\begin{array}{l}\text { Accidental death; } \\
\text { osteoporosis; } \\
\text { spontaneous } \\
\text { fracture and } \\
\text { osteophagy } \\
\text { evident. }\end{array}$ \\
\hline Pt. Reyes & Nov. 79 & $1.5 \mathrm{yr} / \mathrm{male}$ & 10.0 & 2.2 & Accidental death. \\
\hline Concord & Sept. 79 & Adult/female & 88.2 & 1.6 & Accidental death. \\
\hline Concord & Nov. ' 80 & $6 \mathrm{mo} . /$ female & 16.0 & $<0.2$ & Accidental death. \\
\hline Concord & Nov. ' 80 & $6 \mathrm{mo} . / \mathrm{male}$ & 16.0 & $<0.2$ & Accidental death. \\
\hline Concord & Nov. '80 & $6 \mathrm{mo} . /$ female & 17.0 & $<0.2$ & Accidental death. \\
\hline Concord & Nov. 80 & $6 \mathrm{mo} . / \mathrm{male}$ & 21.0 & $<0.2$ & Accidental death. \\
\hline
\end{tabular}

single adult at Concord was $88.2 \mathrm{ppm}$. Liver Mo levels were higher in tule elk at Point Reyes than at Concord. Four young animals at Corcord had Mo levels $<0.2 \mathrm{ppm}$, the minimum detection limit of the analysis used in this study.

Comparison of serum $\mathrm{Cu}$ levels in tule elk sampled at San Luis Island in spring 1978, at the time of transfer to Point Reyes, and 6 subsequent sampling periods at Point Reyes show serum $\mathrm{Cu}$ levels were $>1 \mathrm{ppm}$ prior to $\mathrm{Cu}$ diet supplementation (summer 1979) and subsequent to supplementation (fall and winter 1981) (Fig. 1). Levels in elk at Point Reyes in the fall 1979 through summer 1980 approximate levels in the elk at San Luis Island prior to their translocation to Point Reyes. These levels also approximate those of elk at 3 other locations (Table 2). Serum Mo values are available

Table 2. Serum Cu levels (ppm) in tule elt at locations other than Point Reyes in the fall of 1978 and 1979 combined.

\begin{tabular}{lccc}
\hline \hline Location & $\mathrm{N}$ & $\bar{x}$ & $\mathrm{SE}$ \\
\hline Concord & 3 & 1.73 & 0.25 \\
$\begin{array}{l}\text { Tule Elk State } \\
\text { Reserve }\end{array}$ & 2 & 1.40 & - \\
\begin{tabular}{l} 
Owens Valley \\
\hline
\end{tabular} & 8 & 1.47 & 0.09 \\
\hline
\end{tabular}




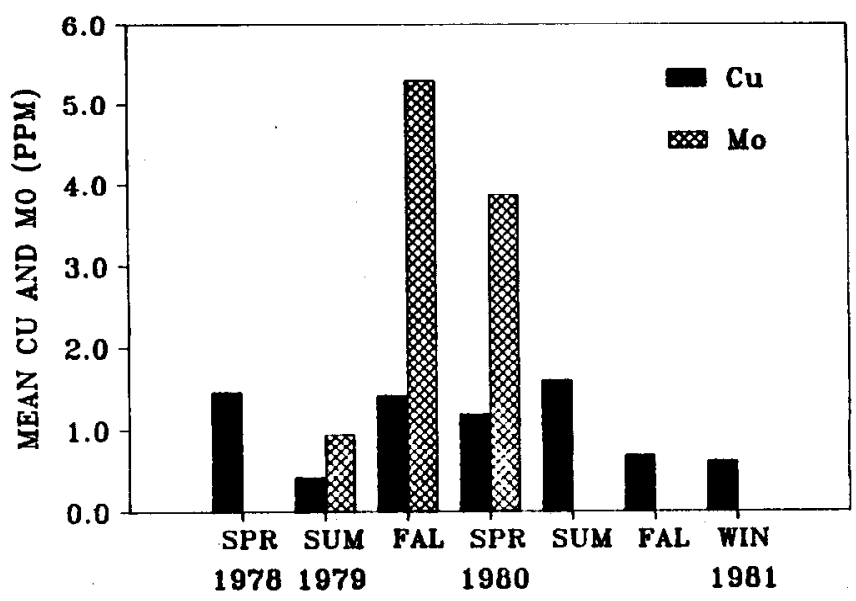

Fig. 1. Serum Cu and Mo levels (ppm) in tule elk at Point Reyes.

only for tule elk at Point Reyes (Fig. 1). Levels were low in the fall 1979 , and rose markedly by summer 1980 .

The emaciated male tule elk transferred from Point Reyes to Grizzly Island first received an injected $\mathrm{Cu}$ supplement and was subsequently fed a Cu-enriched diet through April 1980. Its Cu serum level increased from $0.3 \mathrm{ppm}$ in July 1979 to $1.0 \mathrm{ppm}$ in May 1980 but declined to 0.3 ppm by July 1980 . Its Mo serum level declined from 4.0 ppm in May 1980 to 3.0 ppm by July 1980 .

\section{Soll and Plant Trace Element Levels}

$\mathrm{Cu}$ content of plants was highest in wetland forbs and lowest in grasses and sedges, with dryland forbs and shrubs intermediate (Table 3). However, we found an approximate two-fold difference in $\mathrm{Cu}$ levels within species of both wetland forbs and grasses and considerable overlap between classes of plants. No clear pattern of Mo content was evident within plant groups. The highest plant Mo contents occurred in the group of wetland forbs, but the species with the greatest Mo content was the dryland forb, miner's lettuce
(Montia perfoliata). The Mo level in bush lupine (Lupinus arboreus) was twice that of coyote bush (Baccharis pilularis). Cu:Mo ratios were variable with values of $\geq 7$ recorded in each plant group. S-SO, content was consistent across plant groups.

The concentrations of $\mathrm{Cu}$ in bush lupine increased continuously from October through May whereas the level in plantain increased from October to February and was intermediate in May (Fig. 2).

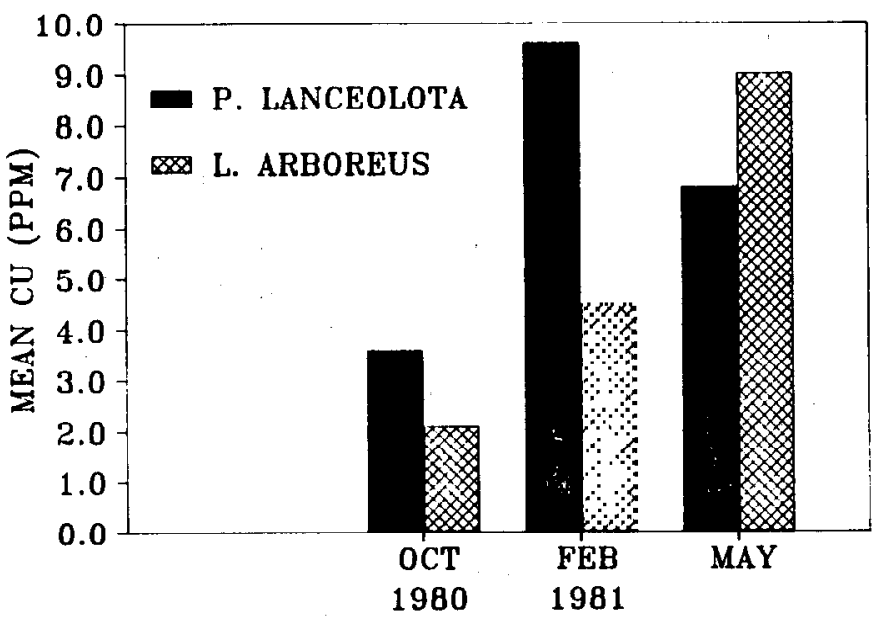

Fig. 2. Changes in seasonal concentrations of $\mathrm{Cu}$ in two common plant species at Point Reyes.

We found little difference in $\mathrm{Cu}$ or Mo levels at different depths within or between soil types (Table 4).

\section{Discussion}

Inadequate metabolic $\mathrm{Cu}$ in herbivores may result from (1) inadequate dietary $\mathrm{Cu}$ (simple $\mathrm{Cu}$ deficiency) or (2) interactions of normally adequate $\mathrm{Cu}$ levels with molybdenum (Mo) and sulfursulfate $\left(\mathrm{S}_{-} \mathrm{SO}_{4}\right)$ resulting in reduced absorption of $\mathrm{Cu}$ or interference with metabolic processes (complex $\mathrm{Cu}$ deficiency) (Mills

Table 3. Cu, Mo and So contents of some Tomales Point common plants of May 1980 . Values are for the entire above ground plant unleas otherwise noted.

\begin{tabular}{|c|c|c|c|c|c|c|c|c|}
\hline \multirow[b]{2}{*}{ Plant group species } & \multirow[b]{2}{*}{$\mathbf{N}$} & \multicolumn{2}{|c|}{$\mathrm{Cu}$} & \multicolumn{2}{|c|}{ Mo } & \multicolumn{2}{|c|}{$\mathrm{SO}_{4}$} & \multirow{2}{*}{$\frac{\text { Ratio }}{\text { Cu:Mo }}$} \\
\hline & & $\overline{\boldsymbol{x}}$ & SE & $\bar{x}$ & SE & $\overline{\boldsymbol{x}}$ & SE & \\
\hline $\begin{array}{l}\text { Grasses/Sedges } \\
\text { Lolium perenne } \\
\text { Bromus rigidus } \\
\text { L. multiflorum } \\
\text { Holcus lanatus } \\
\text { B. mollis } \\
\text { Festuca dertonensis } \\
\text { Juncus effusus }\end{array}$ & $\begin{array}{r}3 \\
8 \\
5 \\
8 \\
25 \\
7 \\
7\end{array}$ & $\begin{array}{l}2.8 \\
3.0 \\
3.1 \\
4.0 \\
4.7 \\
5.0 \\
5.0\end{array}$ & $\begin{array}{l}0.50 \\
0.36 \\
0.55 \\
1.20 \\
0.62 \\
0.91 \\
1.70\end{array}$ & $\begin{array}{l}1.30 \\
0.69 \\
1.10 \\
0.89 \\
0.74 \\
0.71 \\
1.23\end{array}$ & $\begin{array}{l}0.22 \\
0.13 \\
0.51 \\
0.24 \\
0.12 \\
0.24 \\
0.47\end{array}$ & $\begin{array}{r}1100 \\
918\end{array}$ & $\begin{array}{r}144 \\
74\end{array}$ & $\begin{array}{l}2.1: 1 \\
4.4: 1 \\
2.8: 1 \\
4.5: 1 \\
6.4: 1 \\
7.0: 1 \\
4.1: 1\end{array}$ \\
\hline $\begin{array}{l}\text { Dryland forbs } \\
\text { Rumex spp. } \\
\text { Hypochoeris radicata } \\
\text { Marah fabaceus } \\
\text { Montia perfoliata } \\
\text { Plantago lanceolata } \\
\text { Vicia spp." }\end{array}$ & $\begin{array}{r}4 \\
4 \\
4 \\
5 \\
21 \\
5\end{array}$ & $\begin{array}{l}4.0 \\
6.4 \\
6.5 \\
6.8 \\
6.8 \\
5.1\end{array}$ & $\begin{array}{l}1.20 \\
1.50 \\
1.10 \\
2.65 \\
0.79 \\
0.50\end{array}$ & $\begin{array}{l}1.04 \\
1.50 \\
1.10 \\
4.80 \\
1.07 \\
0.67\end{array}$ & $\begin{array}{l}0.28 \\
0.97 \\
0.44 \\
1.15 \\
0.14 \\
0.18\end{array}$ & 970 & 80 & $\begin{array}{l}3.8: 1 \\
4.3: 1 \\
5.9: 1 \\
1.4: 1 \\
6.4: 1 \\
7.6: 1\end{array}$ \\
\hline $\begin{array}{l}\text { Wetland forbs } \\
\text { Hydrocotyle ranunculoides } \\
\text { Mimulus guttatus } \\
\text { Nasturtium officinale }\end{array}$ & $\begin{array}{l}2 \\
6 \\
2\end{array}$ & $\begin{array}{r}6.4 \\
11.0 \\
11.4\end{array}$ & $\begin{array}{l}0.09 \\
1.60 \\
7.21\end{array}$ & $\begin{array}{l}3.50 \\
1.50 \\
2.30\end{array}$ & $\begin{array}{l}1.32 \\
0.32 \\
0.35\end{array}$ & & & $\begin{array}{l}1.8: 1 \\
7.3: 1 \\
5.0: 1\end{array}$ \\
\hline $\begin{array}{l}\text { Shrubs } \\
\text { Baccharis pilularis } \\
\text { Lupinus arboreus }^{\mathrm{b}}\end{array}$ & $\begin{array}{l}13 \\
13\end{array}$ & $\begin{array}{l}7.7 \\
9.0\end{array}$ & $\begin{array}{l}0.98 \\
3.25\end{array}$ & $\begin{array}{l}1.04 \\
2.40\end{array}$ & $\begin{array}{l}0.31 \\
0.41\end{array}$ & 960 & 87 & $\begin{array}{l}7.4: 1 \\
3.8: 1\end{array}$ \\
\hline
\end{tabular}

A composite of leguminous forbs.

Samples of the terminal $8 \mathrm{~cm}$ of new growth. 
Table 4. DPTA extractuble Cu and total Mo in solls of Tomales Point.

\begin{tabular}{|c|c|c|c|c|c|c|c|c|c|c|c|}
\hline \multirow[b]{3}{*}{ Soil type } & \multirow[b]{3}{*}{$\boldsymbol{N}$} & \multicolumn{6}{|c|}{ Soil Depth } & \multicolumn{4}{|c|}{ Pooled } \\
\hline & & \multicolumn{2}{|c|}{$0-15$} & \multicolumn{2}{|c|}{$15-30$} & \multicolumn{2}{|c|}{$30-45$} & \multicolumn{2}{|c|}{$\mathrm{Cu}$} & \multicolumn{2}{|c|}{ Mo } \\
\hline & & $\mathrm{Cu}$ & Mo & $\mathrm{Cu}$ & Mo & $\mathrm{Cu}$ & Mo & $\overline{\boldsymbol{x}}$ & $\mathbf{S E}$ & $x$ & SE \\
\hline $\begin{array}{l}\text { Kehoe Variant } \\
\text { Aquepts } \\
\text { Sirdrak }\end{array}$ & $\begin{array}{l}21 \\
3 \\
5^{a}\end{array}$ & $\begin{array}{l}0.32 \\
0.42 \\
0.31\end{array}$ & $\begin{array}{l}0.15 \\
0.10 \\
0.12\end{array}$ & $\begin{array}{l}0.34 \\
0.54 \\
0.31\end{array}$ & $\begin{array}{l}0.15 \\
0.08 \\
\end{array}$ & $\begin{array}{l}0.33 \\
0.42 \\
\end{array}$ & $\begin{array}{l}0.11 \\
0.18 \\
\end{array}$ & $\begin{array}{l}0.33 \\
0.42 \\
0.31\end{array}$ & $\begin{array}{l}0.04 \\
0.11 \\
0.10\end{array}$ & $\begin{array}{l}0.14 \\
0.11 \\
0.12\end{array}$ & $\begin{array}{l}0.07 \\
0.05\end{array}$ \\
\hline
\end{tabular}

3 samples were analyzed for Mo.

1980). Cu deficiency in wild cervids had been reported as ataxia in adult red deer (C.e. elaphus) (Barlow et al. 1964, Terlecki et al. 1964, Reid et al. 1980, MacKintosh et al. 1986a), osteoporosis in adult reindeer (Rangifer tarandus) (Hyvarinen et al. 1977), and irregular hoof keratinization and reduced reproductive rates in adult moose (Alces alces) (Flynn et al. 1977). Cu deficiency in ungulates may occur in a subclinical form characterized by low liver and serum copper $\mathrm{Cu}$ levels but with individuals appearing normal and showing only marginal signs of poor health (Bingley and Anderson 1972, Thorton et al. 1972b).

Cu liver levels suggest that the Point Reyes tule elk were deficient in this essential trace element during the summer of 1979. Liver $\mathrm{Cu}$ levels for the 3 animals we sampled in 1979 are well below the normal range of between 84 and $142 \mathrm{ppm}$ recorded by McCullough (1969:123) for tule elk at 3 other locations. Values for elk (Cervus elaphus subsp.) in Fiordland National Park, New Zealand, averaged 69 ppm, while free ranging red deer (C.e. subsp.) outside the park averaged $132 \mathrm{ppm}$ (Reid et al. 1980). The average value for red deer from captive herds in the same region, with some evidence of ataxia, was 11 ppm (Reid et al. 1980). Female red deer (C. $e$. elaphus) in Scotland had an average liver $\mathrm{Cu}$ level of $24 \mathrm{ppm}$ with a range of 3-108 ppm (Cowie 1976). Ataxia has been reported in red deer populations in the British Isles (Barlow et al. 1964, Terlecki et al. 1964), and liver $\mathrm{Cu}$ values for one such population were 7-17 ppm (Terlecki et al. 1964:317). Liver copper levels in all red deer in the British Isles diagnosed as ataxic were less than a suggested critical level of 20 ppm (Barlow 1978). However, although no red deer on the Isle of Rhum, Scotland, showed evidence of ataxia, $20 \%$ had liver copper values below 20 ppm but only $2 \%$ had liver copper levels below 10 ppm (McTaggart et al. 1981). Liver copper values of less than $18 \mathrm{ppm}$ have been identifed as diagnostic of copper deficiency in red deer in New Zealand (MacKintosh et al. 1986b). Values for domestic stock experimentally maintained on $\mathrm{Cu}$-deficient diets or diagnosed as $\mathrm{Cu}$-deficient range between 5 and 25 ppm (Allcroft and Parker 1949, Cunningham 1950, Hennings et al. 1973, Stoszek et al. 1979). Normal liver $\mathrm{Cu}$ levels in domestic ruminants range from 100-400 ppm (Underwood 1977).

Serum Cu levels in Point Reyes tule elk were at a low of 0.42 ppm in the summer of 1979 (Fig. 1). Values for the fall 1980 and winter 1981 are only slightly above the summer 1979 samples. The values of $>1.0$ ppm from the fall 1979 through summer 1980 correspond approximately with the period of dietary $\mathrm{Cu}$ supplementation. Serum copper levels of less than 0.5 ppm are considered diagnostic of copper deficiency in red deer (MacKintosh et al. 1986b). Levels of <lppm are comparable to values for $\mathrm{Cu}$-deficient moose (Flynn et al. 1977) and cattle (Hennings et al. 1973). Similarly, serum $\mathrm{Cu}$ values for reindeer exhibiting no signs of nutritional stress were 1.2 ppm, in contrast to levels of $\mathbf{0 . 4} \mathrm{ppm}$ in a herd diagnosed as $\mathbf{C u}$ deficient (Hyvarinen et al. 1977:651).

Our diagnosis of $\mathrm{Cu}$ deficiency in the Point Reyes tule elk was confounded by a concurrent outbreak of paratuberculosis (Jessup et al. 1981). The complexity of interaction between paratuberculosis and $\mathrm{Cu}$ deficiency is not known. However, inflammation of the small intestine, symptomatic of infection with paratuberculosis does inhibit the uptake of nutrients from ingesta. While elk testing positive for paratuberculosis were excluded from our trace element analysis, the unreliability of laboratory tests for the disease preclude any definitive statement on the health status of elk in reference to paratuberculosis. Accordingly, the possibility of paratuberculosis affecting the uptake of $\mathrm{Cu}$ in elk at Point Reyes cannot be excluded. Cattle with paratuberculosis have been shown to be deficient in magnesium, but this was not known to be caused by the disease (Stewart et al. 1945).

We found no evidence of an annual cycle of serum $\mathrm{Cu}$ levels in tule elk at Point Reyes. Our inability to detect seasonal variation may be due to: (1) failure to sample in all seasons, or too small a sample number; (2) the severe disruption of $\mathrm{Cu}$ balance in tule elk at Point Reyes; or (3) masking by Cu-rich diet supplements, or any combination of the foregoing. Seasonal changes in serum $\mathrm{Cu}$ content have been reported in reindeer (Hyvarinen et al. 1977) and sheep (Howell et al. 1968), and for plasma $\mathrm{Cu}$ levels in cattle (Gomm et al. 1982).

Pregnant female elk entering their third trimester of pregnancy and males beginning to grow new antlers in the spring require high $\mathrm{Cu}$ levels. In cattle, the daily maintenance requirement for $\mathrm{Cu}$ increases by approximately $70 \%$ during the third trimester of pregnancy (Agricultural Research Council 1980), and the liver $\mathrm{Cu}$ content of pregnant cattle declines once the fetus is older than approximately 190 days (Pryor 1964). Such high demands for $\mathrm{Cu}$ during pregnancy may explain the drop in reproductive rates characterizing domestic stock suffering $\mathrm{Cu}$ deficiency and tule elk at Point Reyes in 1979 and 1980 (Gogan and Barrett 1987a). A peak demand for $\mathrm{Cu}$ in the spring may have been a contributing cause of death in the $\mathbf{2}$ adult elk that died at Point Reyes in May and June, 1979.

Serum Cu levels in the fall 1980 and winter 1981 were low more than a year after the time when severe $C u$ deficiency was suspected, although none of the external signs observed in 1979 were evident in 1980-1981. These low levels suggest long-term subclinical $\mathrm{Cu}$ deficiency (Bingley and Anderson 1972, Thornton et al. 1972b) possibly attributable to a failure to recover from a severe $\mathrm{Cu}$ deficiency in mid-1979. The low calving rates in 1979 and 1980 (Gogan and Barrett 1987a) support this hypothesis.

Any relationship between $\mathrm{Cu}$ and Mo levels is unclear. Liver Mo levels recorded at Point Reyes are similar to values of 3.4 to 4.5 ppm recorded for tule elk at 3 other sites (McCullough 1969:123). Elk at Point Reyes in the summer 1979 had the highest liver Mo levels recorded in this study and liver Cu:Mo ratios more closely approximate $1: 1$ than at other times for tule elk at Concord (Table 1). Similarly, serum Mo content was higher than serum $\mathrm{Cu}$ content in elk at Point Reyes for 2 of the 3 sample periods (Fig. 1). These high Mo levels in the spring and summer may be caused by ingestion of large quantities of miner's lettuce. The plant is rich in Mo, and constituted more than $20 \%$ of the elk diet in May 1980 and up to $75 \%$ of the diet in April 1981 (Gogan 1986).

$\mathrm{Cu}$ levels in plant species on Tomales Point are low relative to 
those for the same or similar species at other locales. Mean $\mathrm{Cu}$ levels of grasses and low-growing legumes at Tomales Point are 4.4 and $5.1 \mathrm{ppm}$, respectively, compared to 5 and $15 \mathrm{ppm}$ levels for grasses and legumes, respectively, throughout the United States (National Research Council 1977). Similarly, mean Cu levels for plantain, hairy cat's ear (Hypochaeris radicata) and sheep sorrel (Rumex acetosella) in this study (Table 3) are low compared to those of $15.9 \mathrm{ppm}$ for plantain and $10.3 \mathrm{ppm}$ for sheep sorrel in England (Thomas and Thompson 1948) and a mean $\mathrm{Cu}$ level of 18.2 ppm in plaintain and hairy cat's ear in New Zealand (Adams and Elphick 1956). However, Cu levels in Tomales Point forage are similar to levels in forage on the Kenai Peninsula, Alaska, where moose have been diagnosed as Cu-deficient (Kubota et al. 1970).

Mo levels in most of the sampled plant species fall within or below reported normal ranges (Table 3). All grasses typically contain less than $1.5 \mathrm{ppm}$ Mo (Kubota et al. 1970). The low Mo level in velvet grass (Holcus lanatus) is of particular interest. This grass has been identified as an accumulator of Mo in high Mo soils (Fleming 1965); however, at Tomales Point it averaged $<1 \mathrm{ppm}$ Mo at 8 separate sites. Relatively high Mo availability is often associated with wet soil conditions (Kubota et al. 1963) and high levels of soil organic matter (Allaway 1977, Kubota 1977). These conditions may explain the high levels of Mo in wetland forbs as a group. Similarly, the Mo level in bush lupine (a perennial) is markedly lower than the average Mo content of $6 \mathrm{ppm}$ for legumes on alkaline soils in the western United States (Kubota 1977). Yet, total Mo content of the plant may not be a good indicator of its impact on ruminant nutrition. The expression of $\mathrm{Cu}$ deficiency in domestic stock is less severe when the diet is changed from wet to dry or cured vegetation of the same species composition (Davis 1950, Hartmans 1973). This change was associated with a reduction in Mo in the water soluble component of the forage despite little change in total Mo (Ferguson et al. 1943). Thus, high levels of Mo relative to $\mathrm{Cu}$ in cured plant material on Tomales Point in the fall may not be indicative of potential Mo-induced $\mathrm{Cu}$ deficiency in tule elk. The high level of Mo in succulent miner's lettuce at Point Reyes in the spring may have more of an impact on $\mathrm{Cu}$ levels in tule elk.

Similarly, there is evidence to suggest seasonal occurrence of $\mathrm{S}^{-\mathrm{SO}_{4}}$ in the diet. Some inference on the seasonal availability of $\mathrm{S} \mathrm{SO}_{4}$ in the diet may be made upon the percent nitrogen in elk feces (Gogan unpubl. data). Plant organic S-SO, occurs mostly in proteins, and protein contributes most to the nitrogen content of feces. Also, the inorganic S-SO, content of plant tissue tends to be higher during vigorous growth (McPherson et al. 1975). Consequently, highest S-SO 4 ingestion likely corresponds with high percent nitrogen fecal levels from February through April and low levels from August through December (Gogan unpubl. data). Hence, high and low S-SO, intake inferred from percent dietary nitrogen corresponds with high and low $\mathrm{Cu}$ levels as measured by seasonal availability in plants. Yet, Tomales Point is regularly bathed in advective fogs from May through August. Such fogs along the northern California coast have mean S-SO, levels of 0.5 ppm (Azvedo and Morgan 1974). Any increase in S-SO, levels from fog drip is concurrent with the measured decline in $\mathrm{Cu}$ levels in plant material. S-SO, exerts an effect upon the availability of $\mathrm{Cu}$ independent of and greater than Mo (Agricultural Research Council 1980) and $\mathrm{Cu}$ deficiency in moose has been explained more fully by the product of the levels of $\mathrm{Mo}$ and $\mathrm{S}^{-\mathrm{SO}_{4}}$ than by either value separately (Flynn et al. 1976).

Mean values of DTPA-extractable soil Cu (Table 4) are on the low range of values for 178 other California soils, which range from 0.2 to $28 \mathrm{ppm}$ with a mean of $3.8 \mathrm{ppm}$ (Brown and deBoer 1978). This indicates that available soil $\mathrm{Cu}$ is relatively low on Tomales Point. Low extractable $\mathrm{Cu}$ in Tomales Point soils is probably a reflection of low $\mathrm{Cu}$ in the soil parent materials. The Kehoe Variant soil was derived directly from underlying granitic rocks. Soils with low available $\mathrm{Cu}$ are often associated with granitic parent materials (Kubota 1980). Soils of the Sirdrak Series were formed from wind-deposited beach sands or from uplifted beach deposits that originated from weathered Franciscan rocks of the adjacent mainland (Galloway 1977). Such highly weathered, coarse-textured sediments are usually low in metals such as $\mathrm{Cu}$ (Cox 1979). The levels of total soil Mo, coupled with the fact that the soils are predominantly well drained and moderately acid, may contribute to the normal Mo concentrations in plants on Tomales Point (Table 3).

\section{Conclusions}

Tule elk at Point Reyes are susceptible to simple $\mathrm{Cu}$ deficiency resulting from low forage $\mathrm{Cu}$ caused by inherently low levels of $\mathrm{Cu}$ in parent materials and soils. This deficiency may be exacerbated in the spring by higher levels of water-soluble Mo in the forage. Signs of severe deficiency disappeared after dietary supplements were provided to the surviving elk in mid-September 1979. However, low serum $\mathrm{Cu}$ levels in the elk in the fall of 1980 and winter 1981 suggest the elk had entered a period of subclinical $\mathrm{Cu}$ deficiency.

\section{Literature Cited}

Adams, A.F.R., and B.L. Elphick. 1956. The copper content of some soils and pasture species in Canterbury. N.Z.J. Sci. Tech. A. 38:345-358.

Agricultural Rewearch Counell. 1980. The nutrient requirements of ruminant livestock. Commonwealth Agricultural Bureaux. Farnham Royal, England.

Allaway, W.H. 1977. Perspectives on molybdenum in soils and plants. p. 317-339. In: W.R. Chappell and K.K. Peterson (eds), Molybdenum in the environment. Marcel Dekker, Inc., New York.

Allerof, R., and W.H. Parter. 1949. Hypocupraemia in dairy cows. Brit. J. Nutr. 3:205-217.

Azvedo, J., and D.L. Morgan. 1974. Fog precipitation in coastal California forests. Ecology 55:1135-1141.

Balley, E.H., W.P. Irwin, and D.L. Jones. 1964. Franciscan and related rocks and their significance in the geology of western California. Calif. Div. Mines and Geol. Bull. 183.

Barlow, R.M. 1978. Enzootic ataxia of deer, p 65-71. In: R.S. Montali and G. Migaki (eds), Symposium on the comparative pathology of 200 animals. Smithsonian Institute Press, Washington D.C.

Barlow, R.M., E.J. Butler, and D. Purves. 1964. An ataxic condition in red deer (Cervus elaphus). J. Comp. Path. 74:519-529.

Bingley, J.N., and N. Andereon. 1972. Clinically silent hypocuprosis and the effects of molybdenum loading on beef calves in Gippsland, Victoria. Aust. J. Agr. Res. 23:885-904.

Brom, A.L., and G.J. DeBoer. 1978. Soil tests for zinc, iron, manganese and copper. p 40-42 In: H.M. Reisenauer (ed), Soil and plant tissue testing in California. Univ. of California Div. Agr. Sci. Bull. 1879.

Cowie, R.S. 1976. Copper levels in red deer. Vet. Rec. 98(21):434.

Cox, D.P. 1979. The distribution of copper in common rocks and ore deposits. p 19-42 In: J.O. Nriagu (ed), Copper in the environment, John Wiley and Sons, New York.

Cunningham, 1.J. 1950. Copper and molybdenum in relation to diseases of cattle and sheep in New Zealand. p 246-273 In: W.D. McElroy and B. Glass (eds), A symposium on animal, plant and soil relationships. The Johns Hopkins Press, Baltimore.

Curtis, G.N., J.F. Evernden, and J. Lipaon. 19s8. Age determination of some granitic rocks in California by the potassium-argon method. Calif. Div. Mines Special Rep. 54.

Davis, G.K. 1950. The influence of copper on the metabolism of phosphorus and molybdenum. p 216-229 In: W.D. McElroy and B. Glass (eds.), A symposium on animal, plant and soil relationships. The John Hopkins Press, Baltimore.

Elliott, H.W. II. 1982. A study to assess competition and carrying capacity among the ungulates of Point Reyes National Seashore. Unpubl. PhD. Diss., Univ. of California, Davis.

Ferguacon, W.S., A.H. Lewis, and S.J. Watson. 1943. The teart pastures of Somerset. I. The cause and curse of teartness. J. Agr. Sci. Camb. 33:44-51. 
Field, A.C., and D. Purves. 1964. Intake of soil by grazing sheep. Proc. Nutr. Soc. 23:24-25.

Fleming, G.A. 1965. Trace elements in plants with particular reference to pasture species. Outlook on Agriculture 4:270-285.

Flynn, A., A.W. Franamann, and P.D. Ameson. 1976. Molybdenumsulfur interactions in the utilization of marginal dietary $\mathrm{Cu}$ in Alaskan moose (Alces alces gigas). p 115-124 In: W.R. Chapell and K.K. Petersen (eds), Molybdenum in the environment. Vol. I. The biology of molybdenum. Marcel Dekker, Inc., New York.

Flyan, A.A., A.W. Franzman, P.D. Arneson, and J.L. Oldemeyer. 1977. Indications of copper deficiency in a subpopulation of Alaska moose. J. Nutr. 107:1182-1189.

Frieden, E. 1979. Ceruplasmin: the serum copper transport protein with oxidase activity. p. 241-284 In: J.O. Nriagu (ed), Copper in the environment. Part II. John Wiley and Sons, New York.

Galloway, A.J. 1977. Geology of the Point Reyes Peninsula, Marin Co., California. Div. of Mines and Geol. Bull. 202.

Gozan, P.J.P. 1986. Ecology of the tule elk range, Point Reyes National Seashore. Unpubl. PhD. Diss., Univ. of California, Berkeley.

Gomm, F.B.; P.H. Weawis, and R.J. Raleigh. 1982. Copper supplementation of young cattle grazing improved meadow pastures in southeastern Oregon. J. Range Manage. 35:515-518.

Hart, E.B., H. Steenbock, J. Waddell, and C.A. Elveheim. 1928. Iron in nutrition. VII. Copper as a supplement to iron for hemoglobin building in the rat. J. Biol. Chem. 77:797-812.

Hartmans, J. 1973. Tracing and treating mineral disorders in cattle under field conditions. p. 261-273 In: W.G. Hoekstra, J.W. Suttie, H.E. Ganther, and W. Mertz (eds) Trace element metabolism in animals-2. University Park Press, Baltimore.

Heady, H.F., T.C. Foin, M.K. Hektner, D.W. Taylor, M.G. Barbour, and W.J. Barry. 1977. Coastal prairie and northern coastal scrub. p 733-757 In: M.G. Barbour and J. Major (eds.), Terrestrial vegetation of California. John Wiley \& Sons, Ltd., New York.

Healy, W.B., W.J. McCabe, and G.F. Wilson. 1970. Ingested soils as a source of micro-elements for grazing animals. N.Z. Agr. Res. 13:503-521.

Henning, A., M. Anke, B. Groppel, and H. Ludke. 1973. Secondary copper deficiency in ruminants. p. 726-729 In: W.G. Hoekstra, J.W. Suttie, H.E. Ganther, and W. Mertz (eds), Trace element metabolism in animals-2. University Park Press, Baltimore.

Howell, J. McC., N. Eddington, and R. Ewbank. 1968. Observations on copper caeruloplasmin levels in the blood of pregnant ewes and lambs. Res. Vet. Sci. 9:160-164.

Howell, J.T. 1970. Marin flora. 2nd ed. Univ. Calif. Press, Berkeley.

Hyvarinen, H., I. Helle, and M. Nieminen, P. Vayrynen, and R. Vayrynen. 1977. The influence of nutrition and seasonal conditions on mineral status in the reindeer. Can. J. Zool. 55:648-655.

Irwin, M.R., P.W. Poulos, Jr., B.P. Smith, and G.L. Fisher. 1974. Radiology and histopathology of lameness in young cattle with secondary copper deficiency. J. Comp. Pathol. 84:611-621.

Jeseup, D.A., B. Abbas, D. Behymer, and P. Gogan. 1981. Paratuberculosis in tule elk in California. J. Amer. Vet. Med. Assoc. 179:1252-1254.

Johnson, C.M., and H. Nishita. 1952. Microestimation of sulfur in plant material, soil, and irrigation waters. Anal. Chem. 24:736-742.

Kubota, J. 1977. Molybdenum status of United States soils and plants. p 525-554 In: W.R. Chappell and K.K. Peterson (eds), Molybdenum in the environment. Marcel Dekker, Inc., New York.

Kubota, J. 1980. Regional distribution of trace element problems in North America. p 441-466 In: B.E. Davies (ed), Applied soil trace elements. John Wiley and Sons, Ltd., New York.

Kubota, J., E.R. Lemon, and W.H. Allaway. 1963. The effect of soil moisture content upon the uptake of molybdenum, copper and cobalt by alsike clover. Soil Sci. Soc. Amer. Proc. 27:679-683.

Kubota, J., S. Rieger, and V.A. Lazar. 1970. Mineral composition of herbage browsed by moose in Alaska. J. Wildl. Manage. 34:565-569.

Kuchler, A.W. 1977. The map of the natural vegetation of California. $p$ 909-938 In: Barbour, M.G., and J. Major, (eds.), Terrestrial vegetation of California. John Wiley \& Sons, Ltd., New York.
Mackintosh, C.G., M.B. Orr, and K. Tumer. 19a6a. Enzootic ataxia in wapiti. Proc. Deer Branch N. Zeal. Vet. Assoc. Course 3:165-169.

Mackintosh, C.G.P.R. Wlison, N.S. Beatson, K. Turner, and P. Johnston. 1986b. Preliminary report of the liver:serum copper relationship in red deer. Proc. Deer Branch N. Zeal. Vet. Assoc. Course 3:156-164.

Mason, J. 1970. Point Reyes. The solemn land. DeWolf Printing, Point Reyes, Calif.

MeCullough, D.R. 1969. The tule elk: its history, behavior and ecology. Univ. Calif. Publ. Zoology 88:1-209.

Mills, C.F. 1980. Metabolic interactions of copper with other trace elements. p 49-69 In: D. Evered, and G. Lawrenson (eds), Biological roles of copper Exerta medica. Ciba Foundation Symposium 79 (new series). Amsterdam.

Minard, C.R., Jr. 1971. Quaternary beaches and coasts between the Russian River and Drake's Bay, California. Univ. of Calif. Hyd. Eng. Lab. HEL-2-35.

National Research Council. 1977. Medical and biological effects of environmental pollutants: copper. Nat. Acad. Sci., Washington, D.C.

Owen, C.A., Jr. 1981. Copper deficiency and toxicity: acquired and inherited, in plants, animals, and man. Noyes Publ., Park Ridge, N.J.

Owen, C.A., Jr. 1982. Biochemical aspects of copper: copper proteins, ceruloplasmin, and copper protein binding. Noyes Publ., Park Ridge, N.J.

Pryor, W.J. 1964. The distribution of copper in bovine and ovine foetuses, with reference to age and maternal liver copper concentrations. Res. Vet. Sci. 5:123-137.

Ray, D.T. 1981. Post-release activity of tule elk at Point Reyes National Seashore, California. Unpubl. M.S. thesis, Univ. of Michigan, Ann Arbor.

Reid, T.C., H.J.F. McAllum, and P.D. Johnstone. 1980. Liver copper concentrations in red deer (Cervus elaphus) and wapiti ( $C$. canadensis) in New Zealand. Res. in Vet. Sci. 28:261-262.

Stewart, J.J., W. McCallum, and A.W. Taylor. 1945. Observations on the blood picture of Johne's disease in sheep and cattle with special reference to the magnesium content of the blood. J. Comp. Path. 55:45-48.

Stoszek, M.J., J.E. Oldfield, G.E. Carter, and P.H. Weswig. 1979. Effect of tall fescue and quackgrass on copper metabolism and weight gains of beef cattle. J. Anim. Sci. 48:893-899.

Suttle, N.F., B.J. Alloway, and I. Thornton. 1975. An effect of soil ingestion on the utilization of dietary copper by sheep. J. Agr. Sci. Camb. 84:249-254.

Suttle, N.F., and M. McLaughlan. 1976. Predicting the effects of dietary molybdenum and sulfur on the availability of copper to ruminants. Proc. Nutr. Soc. 35:22A.

Teriecki, S., J.T. Done, and F.G. Clezs. 1964. Enzootic ataxia of red deer. Brit. Vet. J. 120:311-321.

Thomas, B., and A. Thompson. 1984. The ash content of some grasses and herbs on the Palace Leas hay plots at Cockle Park. Emp. J. Exp. Agr. 16:221-230.

Thomton, 1. 1973. Biochemical and soil ingestion studies in relation to the trace-element nutrition of livestock. p. 451-454 In: W.G. Hoekstra, J.W. Suttie, H.E. Ganther, and W. Mertz (eds), Trace element metabolism in animals-2. University Park Press, Baltimore.

Thornton, I., G.F. Kershaw, and M.K. Davies. 1972a. An investigation into copper deficiency in cattle in the Southern Pennines. I. Identification of suspect areas using geochemical reconnaissance followed by blood copper surveys. J. Agr. Sci. 78:157-163.

Thornton, I., G.F. Kershaw, and M.K. Davies. 1972b. An investigation into copper deficiency in cattle in the Southern Pennines. II. Response to copper supplementation. J. Agr. Sci. 78:165-171.

Underwood, EJ. 1977. Trace elements in human and animal nutrition. 4th ed. Academic Press, New York.

Weaver, C.E. 1949. Geology of the coast ranges immediately north of the San Francisco Bay Region, California. Geol. Soc. Amer. Memoir. 35. 